\title{
ОСОБЕННОСТИ РЕАЛИЗАЦИИ ИНСТРУМЕНТОВ ИМПОРТОЗАМЕЩЕНИЯ В ПИЩЕВОЙ ПРОМЫШЛЕННОСТИ РОССИЙСКОЙ ФЕДЕРАЦИИ
}

\author{
(c) 2019 Туфетулов Айдар Миралимович \\ доктор экономических наук, профессор, \\ заведующий кафедрой экономической безопасности и налогообложения \\ Казанский (Приволжский) федеральный университет, Респ. Татарстан, Казань \\ E-mail: ajdar-t@yandex.ru \\ (c) 2019 Мингазов Минтимер Вагизович \\ аспирант кафедры экономической безопасности и налогообложения \\ Казанский (Приволжский) федеральный университет, Респ. Татарстан, Казань \\ E-mail: mintik001@mail.ru
}

Отраслевые особенности предприятий пищевой отрасли и зависимость показателей их функционирования от относительных и абсолютных преимуществ территории размещения предполагает необходимость адаптации традиционных инструментов стимулирования процессов импортозамещения к данному сектору экономической деятельности. В статье представлен обзор эволюции импортозамещающих мероприятий в государствах Латинской Америки, Юго-Восточной Азии в период с 1940 по 1980 годы. Проанализированы четыре методических подхода к трактовке сущности процессов импортозамещения, сложившихся в российской экономической науке, и предложена терминологическая конструкция «инновационное импортозамещение». Сделан вывод о необходимости использования адресных мер, стимулирующих импортозамещение в пищевой промышленности в современной России с учетом природно-климатических условий и адаптационного потенциала отдельных субъектов хозяйствования.

Ключевые слова: Пищевая промышленность, продовольственная безопасность, инновационное импортозамещение, качество продовольственных товаров, конкурентоспособность предприятий импортозамещения, качество жизни населения.

Вне зависимости от господствующего типа хозяйственного уклада, фазы экономического цикла и провозглашенных государством приоритетов развития пищевая промышленность является одним из ключевых сегментов национальной экономики, что обусловлено ее ролью в обеспечении продовольственной безопасности, уровня и качества жизни населения, а также поступательной динамики основных макроэкономических индикаторов. Устойчивое развитие показателей финансово-хозяйственной деятельности предприятий пищевой промышленности выступает необходимой предпосылкой обеспечения населения продовольственными товарами в соответствии с нормативами, учитывающими условия расширенного воспроизводства. Указанные обстоятельства определили особую актуальность разработки и внедрения инструментов импортозамещения, направленных на сохранение объемов и структуры потребления продуктов питания в условия введения санкционных ограничений на их ввоз на терри- торию Российской Федерации со стороны ряда зарубежных государств.

Согласно данным Центра конъюнктурных исследований Института статистических исследований и экономики знаний Национального исследовательского университета Высшей школы экономики, которые нашли отражение в публикации «Факторы, ограничивающие деятельность организаций базовых отраслей экономики в 2017 г.», 64 проц. руководителей предприятий указали на низкий уровень конкурентоспособности [10] их продукции. При этом она продолжает реализовываться на внутреннем рынке, что подтверждает слабое развитие конкуренции в национальной экономике в целом. В качестве причин, сдерживающих процессы импортозамещения, указывается на высокий износ основных фондов в экономике в целом и добывающих и перерабатывающих отраслях промышленности в частности, а также низкие объемы совокупного спроса и инвестиций как составляющей совокупных расходов. Действие указанных фак- 
торов в долгосрочном периоде вызывает риски технологического отставания национальной экономики, что может стать причиной сдерживания темпов экономического развития.

Противоречивость сложившейся ситуации заключается в том, что с одной стороны, она характеризуется необходимостью реализации мер, направленных на стимулирование российских производителей с целью замещения импортных товаров отечественной продукцией, с другой стороны, потребностью в импорте как в условии формирования технологической базы для стимулирования объемов производства и повышения уровня конкурентоспособности. Для обоснования методических подходов к решению ключевой проблемы обеспечения устойчивого развития национальной экономики и повышения конкурентного потенциала субъектов хозяйствования представляется необходимым проанализировать концепцию импортозамещения, выявить границы и возможности ее применения в условиях современной России.

Нормативное оформление указанные инструменты получили в ряде подзаконных актов, среди которых: Указ Президента РФ от 6 августа 2014 года № 560 «О применении отдельных специальных экономических мер в целях обеспечения безопасности Российской Федерации» [9], Постановление Правительства Российской Федерации от 4 августа 2015 года № 785 «О создании правительственной комиссии по импотрозамещению» [5] и др. Согласно Плану содействия импортозамещению в промышленности, утвержденному распоряжением Правительства Российской Федерации от 30 сентября 2014 г. № 1936-р, и соответствующим отраслевым планам импортозамещения [6], к 2020 г. предполагалось существенно снизить долю импортной продукции в машиностроении, электроэнергетике, гражданской авиации, станкостроении, нефтегазовой отрасли и других видах экономической деятельности. Однако начало реализации процессов импортозамещения в сфере производства продовольственных товаров было положено в 2012 году, что нашло отражение в Государственной программе развития сельского хозяйства на 2013-2020 гг. [4]. Это показывает, что санкционные ограничения, введенные со стороны западных стран, лишь предопределили необходимость актуализации мер стимулирования процессов замещения импортного продовольствия отечественной продукцией, но не играли роль решающего фактора при разработке соответствующих мер государственного регулирования.

Для реализации мероприятий для решения поставленных задач было выделено в течение 2016 г. 374,4 млрд. руб., из которых почти 105 млрд. руб. составили инвестиции в рамках прямой государственной поддержки [11]. Согласно официальным данным, в результате принятых мер доля импортной продукции в общем объеме потребительских товаров на розничном рынке сократилась в период с 2014 г. по 2017 г. с 42 проц. до 35 проц., доля продуктов питания - с 34 проц. до 22 проц. [11]. Однако при этом ключевая задача импортозамещения, которая заключается в повышении качества и уровня конкурентоспособности отечественных товаров с учетом бюджетных ограничений потребителей [1], не решена в настоящее время.

Аграрная сфера и пищевая промышленность изначально рассматривались в качестве ключевого объекта применение инструментов импортозамещения, что нашло отражение в Доктрине продовольственной безопасности, где были определены «пороговые значения удельного веса отечественной продукции в общем объеме товарных ресурсов (с учетом переходящих запасов) внутреннего рынка соответствующих продуктов для ряда продуктов питания (сахар, мясо и мясопродукты, молоко и молочные продукты, рыба и рыбопереработка и др.)» [8]. Впоследствии указанный перечень продовольственных товаров вошел в список продукции, в отношении которых были установлены санкционные ограничения, что стало дополнительным стимулом для развития российской пищевой индустрии. Предполагалось, что «политика импортозамещения позволит к 2020 г. увеличить производство мяса скота и птицы (в убойной массе) до 10 млн. т, что снизит поставки ввозного мяса на 67,8 проц. Примерно на 30 проц. должен сократиться импорт молока и на 70 проц.- овощей» [3]. Согласно официальным данным, доля импорта в общем объеме пищевой продукции и сельскохозяйственного сырья в период с 2013 по 2017 гг. действительно сократилась с 43 млрд. долл. до 23,3 млрд. долл. [2]. Наряду с мерами в рамках реализации стратегии импортозамещения, существенную роль сыграли ограничения ввоза отдельных видов продовольственных товаров, предпринятые российским государством в ответ на внешнеэкономические санкции, а 
также ослабление курса национальной валюты. Однако несмотря на снижение объемов импорта показатели ввоза по отдельным категориям продуктов питания продолжают оставаться значительными. Так, например, в указанный период объем ввоза свинины в стоимостном выражении сократился в 2,4 раза, мяса птицы - в 2,5 раза, в натуральном выражении - примерно в 2 и 2,4 раза соответственно составляет лишь $8,3 \%$ и $4,4 \%$ от российского производства [7]. Заметно сократился ввоз молочной продукции, мороженой рыбы, сахара и кондитерских изделий, отдельных видов овощей и фруктов и др. При этом наблюдается повышение объема импорта отдельных видов продовольствия и сельскохозяйственного сырья, что, прежде всего, относится к товарам, которые не производятся в России вследствие природно-климатических условий. Например, в период с 2013 по 2017 гг. увеличились объемы импорта бананов (в стоимостном выражении - с 996 млн. долл. до 1,1 млрд. долл.) и пальмового масла в натуральном выражении - с 747 тыс. т до 872 тыс. т). Невозможность полного отказа от ввоза отдельных видов продовольственных товаров наряду с природно-климатическими факторами объясняется необходимостью развития конкуренции и обеспечения ценовой доступности продукции для потребителей, а также высокой зависимостью производителей сельскохозяйственной продукции от импорта семян и оборудования для предприятий пищевой промышленности. Существенной проблемой остается проблема обеспечения должного качества продукции отечественного производства. Так, Федеральная служба по надзору в сфере защиты прав потребителей и благополучия человека отмечает высокую долю творога, сливочного масла, молока и других товаров отечественного производства, которые не соответствуют обязательным нормам.

Проведенный анализ показывает, что реа- лизация традиционной модели импортозамещения в пищевой промышленности в условиях постиндустриальной экономики не представляется целесообразной вследствие ряда негативных последствий для показателей конкурентоспособности производителей и их продукции, динамики цен на продовольственные товары и уровня жизни населения, а также качества продукции.

В этой связи представляется необходимым разработка стратегии инновационного импортозамещения, которая не предполагает тотального отказа от импорта продовольственных товаров и сельскохозяйственного сырья, ориентирует производителей на сбалансированное развитие различных видов импортозамещающих производств, внедрение продуктовых, управленческих и технологических инноваций. При этом ряд ресурсных ограничений не позволяет в равной степени применять инструменты импортозамещения ко всем секторам промышленного производства. В этой ситуации пищевая промышленность может рассматриваться как сфера экономической деятельности, которая обладает рядом отраслевых преимуществ, необходимых для реализации импортозамещающих мероприятий в рамках в рамках промышленной политики. В этой ситуации имеет место потребность в разработке национальной модели инновационного импортозамещения и ее адаптация к особенностям отдельных региональных образований, различающихся по содержании абсолютных и относительных преимуществ. Результатом применения инструментов импортозамещения в сфере производства продовольственных товаров выступают технологическая модернизация производства и повышение его эффективности с целью укрепления позиции отечественной продукции на национальном и мировом отраслевых рынках.

\section{Библиографический список}

1. Мантуров Д. Нашей задачей был и остается выход на мировой рынок [Электронный ресурс] Режим доступа: https://news.rambler.ru/other/38901887-denis-manturov-nashey-zadachey-byl-i-ostaetsya-vyhod-namirovoy-rynok/. Дата обращения: 12.10.2019.

2. Официальный сайт Федеральной таможенной службы [Электронный ресурс] Режим доступа: http://customs. ru/. Дата обращения: 12.10.2019.

3. Петыш Я.С. Импортозамещение в пищевой промышленности: специфика хлебопекарной отрасли и сегмента ингредиентов для хлебопечения /Я. С. Петыш/ Кондитерское и хлебопекарное производство. 2016. № $-5-6$. 
4. Постановление Правительства Российской Федерации от 14 июля 2012 года № 717 «О Государственной программе развития сельского хозяйства и регулировании рынков сельскохозяйственной продукции, сырья и продовольствия» [Электронный ресурс] Режим доступа: www. government.ru/ rugovclassifier/815/events/ Дата обращения: 12.10 .2019 .

5. Постановление Правительства Российской Федерации от 4 августа 2015 года № 785 «О создании правительственной комиссии по импортозамещению» (с изменениями и дополнениями) [Электронный ресурс] Режим доступа: www. base.garant.ru/71152492/ Дата обращения: 12.10.2019.

6. Приказ Министерства промышленности и торговли Российской Федерации «Об утверждении плана мероприятий по импортозамещению в станкоинструментальной промышленности Российской Федерации» [Электронный ресурс] Режим доступа: http://minpromtorg.gov.ru/common/upload/o_data/addition_ material//650_stankoinstr.pdf. Дата обращения: 12.10.2019.

7. Топ-25 продуктов, которые мы импортируем [Электронный ресурс] Режим доступа: https://www.agroinvestor. ru/rating/article/30319-top-25-produktov-kotorye-my-importiruem/ Дата обращения: 12.10.2019.

8. Указ Президента РФ от 30 января 2010 года № 120 «Об утверждении Доктрины продовольственной безопасности Российской Федерации» [Электронный ресурс] Режим доступа: http://base.garant.ru/12172719/ Дата обращения: 12.10.2019

9. Указ Президента РФ от 6 августа 2014 года № 560«О применении отдельных специальных экономических мер в целях обеспечения безопасности Российской Федерации» (с изменениями и дополнениями) [Электронный ресурс] Режим доступа: www. base.garant.ru/70711352/ Дата обращения: 12.10.2019.

10. Факторы, ограничивающие деятельность организаций базовых секторов экономики в 2017 году. Информационно-аналитический материал Центра конъюнктурных исследований ИСИЭЗ НИУ ВШЭ. Режим доступа: https://issek.hse.ru/news/217521256.html. Дата обращения: 12.10.2019.

11. Что не так с импортозамещением // Ведомости. 23 апреля 2018 г. [Электронный ресурс] Режим доступа: www.vedomosti.ru/opinion/articles/2018/04/23/767453-ne-tak-s-importozamescheniem. Дата обращения: 12.10.2019. 